\title{
HPLC identification and determination of myricetin, quercetin, kaempferol and total flavonoids in herbal drugs
}

\author{
Svetlana Kulevanova ${ }^{*}$, Marina Stefova ${ }^{2}$, Tatjana Kadifkova Panovska ${ }^{3}$, Trajce Stafilov ${ }^{2}$ \\ ${ }^{1}$ Institute of Pharmacognosy, Faculty of Pharmacy, Vodnjanska 17, 1000 Skopje, R. Macedonia \\ 2 Institute of Chemistry, Faculty of Science, P. O. Box 162, 1001 Skopje, R. Macedonia \\ 3 Institute of Toxicology, Faculty of Pharmacy, Vodnjanska 17, 1000 Skopje, R. Macedonia
}

Received September 2003; accepted May 2003

\begin{abstract}
A new and rapid HPLC method for identification and determination of myricetin, quercetin, kaempferol and total flavonoids in ten herbal drugs of Macedonian origin is presented. Preparation of samples (Uvae ursi folim, Pruni spinosae flos, Sambuci flos, Betulae folim, Primulae flos, Herniariae herba, Centaurii herba, Tiliae flos, Robiniae pseudoacaciae flos, Bursae pastoris herba) included hydrolysis of glycosides and extraction of total aglycones with ethyl acetate. HPLC analysis with UV-diode array detection was carried out on RP C18 column, using 5\% acetic acid and acetonitrile in agradient elution mode and column temperature of $30{ }^{\circ} \mathrm{C}$. The monitoring of the elution is performed in the whole UV-range and the acquisition of data for quantitative analysis at $367 \mathrm{~nm}$. Screening of the extracts showed presence of quercetin in nine, kaempferol in seven and myricetin in only one sample. The quantitative analysis showed that the content of quercetin ranged from $0.026-0.506 \%(\mathrm{~m} / \mathrm{m})$, while for kaempferol it was from traces to $1.246 \%$. Uvaeursi folium and Pruni spinosae flos were rich in content of quercetin ( $0.482 \%$ and $0.506 \%$, respectively), while Pruni spinosae flos and Robiniae pseudoaccaciae flos contained the highest amounts of kaempferol (1.246\% and $0.892 \%$, respectively). Myricetin was identified and determined only in Betulae folium $(0.102 \%)$. The content of total flavonoids in the investigated samples expressed in terms of quercetin ranged from 0.040 to $1.680 \%$. The proposed HPLC method is convenient for use in routine analysis of myricetin, quercetin and kaempferol, as well as for estimation of total flavonoids content in herbal drugs.
\end{abstract}

Key words: flavonols, quercetin, kaempferol, HPLC, determination

\section{Introduction}

A lot of commonly used herbal drugs are appreciated in phytotherapy because of their flavonoid pattern. Flavonoids have showed wide range of pharmacological activities, including antioxidant, antimicrobial, spazmolytic, diuretic, capilary protection, citostatic, etc (1-3). Quercetin is the most important flavonol and many of the above mentioned activities are due to its presence (1-6). Besides quercetin, kaempferol and myricetin are also widely spread in the plant kingdom (7).

The content of total flavonoids in plant materials has been usually determined by spectrophotometric method with $\mathrm{AlCl}_{3}$ (8). The reaction between flavonoids with $\mathrm{OH}$-group at $\mathrm{C}-3$ and/or $\mathrm{C}-5$ positions and $\mathrm{Al}^{3+}$ ions was

\footnotetext{
* e-mail: svku@baba.ff.ukim.edu.mk

Tel: 38902 126-032 Fax 38902 123-054
}

used for establishing a spectrophotometric method for determination of total flavonoids in Betulae folium (9). The same method can be used for analysis of total flavonoids in Sambuci flos or Tiliae flos (5). For the other herbal drugs, it is recommended to check the accuracy and reproducibility of the method.

Nowadays, high performance liquid chromatography (HPLC) with spectrophotometric or electrochemical detection is the method of choice for identification and quantification of flavonoids. Besides other advantages, the method gives the opportunity of simultaneous identification and determination of flavonoids in plant extracts. Some of recently published data considering HPLC measurements of flavonols in fruits, vegetables, beverages (10$13)$ and berry wines $(14,15)$ confirm the wide range of possibilities of HPLC in flavonoid analysis in different kinds of natural materials. 
Examination of flavonoids in Macedonian medicinal plants was recently made for Helychrisum plicatum, Hypericum perforatum, a large number of wild Thymus species, etc. (16-18). Continuing our work on flavonoids in medicinal plants, several herbal drugs used in Macedonian folk medicine as spazmolytic, diuretic, antimicrobial and diaphoretic agents (19) were chosen for further examination. According to literature data, determination of total flavonoids with the above mentioned spectrophotometric method is recommended for some of them $(5,8,9)$. For the other specimens no method for determination of flavonoids has been suggested until now. The present work is a contribution to the research of developing methods for identification and quantification of flavonoids in different herbal drugs using HPLC method.

\section{Experimental}

\section{Materials}

Plant material: parts of plants (leaves, herbs, flowers) were collected in the blooming season during summer 1999 and 2000 at different locations throughout the whole territory of Macedonia. The materials were air-dried, milled, packed in paper bags and kept in a dark and cool place until analysis. The following specimens were included in the investigation: Uvae ursi folim, leaves of Arctostaphylos uva-ursi (L.) Spreng; Pruni spinosae flos, flowers of Prunus spinosa L.; Sambuci flos, flowers of Sambucus nigra L.; Betulae folim, leaves of Betula pendula Roth.; Primulae flos, flowers of Primula veris L., Herniariae herba, herbs of Herniaria glabra L.; Centaurii herba, herbs of Erythraea centaurium (L.) Pers.; Tiliae flos, flowers of Tilia platyphyllos Scop.; Bursae pastoris herba, herbs of Capsela bursa pastoris (L.) Med., and Robiniae pseudoacaciae flos, flowers of Robinia pseudoacacia $\mathrm{L}$.

Reagents and authentic samples: The applied reagents were of the highest purity (>99.95), acetonitrile HPLC grade and glacial acetic acid (Merck, Darmstadt, Germany), authentic samples of myricetin, quercetin, and kaempferol (Extrasynthese, Lyon, France).

\section{Extraction procedure}

Milled plant material (2 g) was extracted twice with 50 $\mathrm{ml}$ of acetone, $2 \mathrm{ml}$ of concentrated $\mathrm{HCl}$ and $1 \mathrm{ml}$ of $1 \%$ solution of urotropine in water, each time. The extraction was performed in an Erlenmeyer flask with reflux on a boiling water bath for $30 \mathrm{~min}$. The extract was then cooled, filtered and filled to volume with acetone $(100 \mathrm{ml})$. Then $25 \mathrm{ml}$ of this extract were transferred to a separating funnel, $50 \mathrm{ml}$ of water was added and extraction with eth$\mathrm{yl}$ acetate was repeated 3 times with $15 \mathrm{ml}$ each. The ethylacetate fractions were collected and washed three times with $50 \mathrm{ml}$ of water each, then dried with anhydrous
$\mathrm{Na}_{2} \mathrm{SO}_{4}$, filtered and evaporated to dryness under low pressure. The residue was dissolved and filled to $10 \mathrm{ml}$ with methanol and this solution was used for identification and quantification of flavonols by HPLC.

\section{HPLC analysis}

A Varian HPLC system equipped with a ternary pump Model 9012 and UV-Diode Array detector Model 9065 and a reverse phase column C18 $(250 \times 4.6 \mathrm{~mm}, 5 \mathrm{~mm}$ particle diameter) were used. The mobile phase consisted of two solvents: $5 \% \mathrm{CH}_{3} \mathrm{COOH}(\mathrm{A})$ and $\mathrm{CH}_{3} \mathrm{CN}(\mathrm{B})$ and the elution program was the following: 0-10 $\min 70 \%$ Asocratic, $10-20$ min gradient to $40 \%$ A and then $20-30 \min 40 \%$ A isocratic again. The flow rate was $1.0 \mathrm{ml} / \mathrm{min}$ and the temperature was set to $30 \mathrm{\epsilon C}$. The elution was monitored in the UV range and the acquisition of data for quantitative analysis was performed at $367 \mathrm{~nm}$.

Calibration was made in the concentration range of 0.049-0.490 $\mathrm{mg} / \mathrm{ml}$ myricetin; 0.086-0.860 mg/ml quercetin and 0.094-0.940 mg/ml kaempferol. The limit of detection (LOD) and limit of quantification (LOQ) were established by construction of a calibration curve in the low concentration region $(0.005-0.05 \mathrm{mg} / \mathrm{ml})$ for quercetin.

\section{Results and discussion}

The results from the screening HPLC analysis of the extracts obtained after hydrolysis showed that the main flavonol component in the majority of samples was quercetin, followed by kaempferol. Identification of flavonols

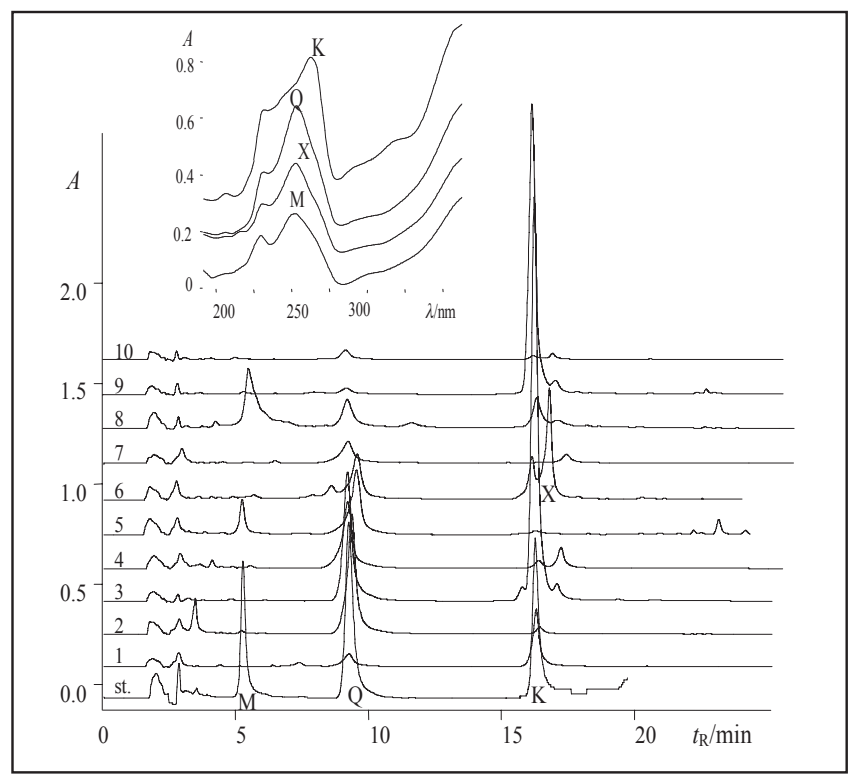

Fig. 1. Chromatograms obtained for a mixture of authentic samples of myricetin (M), quercetin (Q) and kaempferol (K) and from the extracts numbered from 1-10 as in Table 2, with detection at $367 \mathrm{~nm}$ ( $\mathrm{X}$ is the unknown flavonol component) together with the UV-spectra of the flavonoid components 
Table 1. Results of the qualitative analysis of flavonols in plant extracts after hydrolysis

\begin{tabular}{|c|c|c|c|c|c|}
\hline & Plant material & $\begin{array}{c}\text { Myricetin (M) } \\
t_{R^{-}}-5.4\end{array}$ & $\begin{array}{c}\text { Quercetin (Q) } \\
t_{R^{-}} 9.4\end{array}$ & $\begin{array}{c}\text { Kaempferol }(\mathrm{K}) \\
t_{R^{-}}-16.3\end{array}$ & $\begin{array}{c}\text { Unknown (X) } \\
t_{R}-16.9\end{array}$ \\
\hline 1 & Tiliae flos & - & + & +++ & - \\
\hline 2 & Uvae ursi folium & - & +++++ & + & - \\
\hline 3 & Pruni spinosae flos & - & +++++ & +++++ & + \\
\hline 4 & Sambuciflos & - & ++++ & + & ++ \\
\hline 5 & Betulae flos & + & ++++ & - & - \\
\hline 6 & Primulae flos & - & +++ & ++ & ++++ \\
\hline 7 & Herniariae herba & - & ++ & traces & ++ \\
\hline 8 & Centaurii herba & - & ++ & ++ & - \\
\hline 9 & Robiniae pseudoacaciae flos & - & traces & +++++ & - \\
\hline 10 & Bursae pastoris herba & - & + & + & - \\
\hline
\end{tabular}

* not found in the extract; ${ }^{* *}$ relative quantity approximated in relation to peak area at $367 \mathrm{~nm}$.; $t_{R}$ - retention time in $\min$

was performed by comparing the chromatograms obtained from the samples to the one obtained for the mixture of the authentic samples of myricetin, quercetin and kaempferol (Fig. 1, Table 1), using the retention times together with the UV-spectra of the studied flavonols. The retention times obtained for myricetin, quercetin and kaempferol were 5.4; 9.4 and $16.3 \mathrm{~min}$, respectively. This elution sequence is directed by their structural characteristics. All three flavonols have the same substitution pattern in the A flavone ring. Consequently, their elution pattern depends only on the substitution in the B ring, which is as follows: kaempferol has one $\mathrm{OH}$-group in position 4', quercetin two OH-groups at 3', 4' and myricetin three OH-groups at 3', 4', 5' in the B-ring. As expected, the retention is affected by the number of $\mathrm{OH}$-groups and the order of elution from the reverse phase column follows the rule: more polar $(\mathrm{OH})$ groups » less retention on the reversed phase (non-polar) column » shorter retention time.

Screening of the extracts showed that quercetin is the most abundant flavonol in Uvae ursi folium, Pruni spinosae folium, Sambuci flos and Betulae folium, lesser amount was found in Primulae flos, Herniariae herba, Centaurii herba, Tiliae flos and Bursae pastoris herba, and only traces in Robiniae pseudoacaciae flos. Kaempferol was found to be most abundant in Pruni spinosae flos, Robiniae pseudoacaciae flos and Tiliae flos, whereas myricetin was identified only in Betulae folium. An unknown flavonoid component was found in the extracts of Primulae flos, Herniariae herba, Sambuci flos and Pruni spinose flos. Its UV-spectrum, which is almost identical to the one of quercetin, and retention time close to kaempferol suggests that this is most probably quercetin with one methylated $\mathrm{OH}$-group (20).

The HPLC method used for screening analysis was then employed for quantitative analysis of myricetin, quercetin and kaempferol. $367 \mathrm{~nm}$ was selected as optimal wavelength for taking the areas of the peaks for quantification because of the better selectivity for all three components and the better sensitivity for myricetin and kaempferol compared to $254 \mathrm{~nm}$ (for quercetin no significant difference in sensitivity was observed). The linear dependence of the mass concentration of myricetin, quercetin and kaempferol injected in the column was established in the examined ranges and the linear regression equations, obtained at 254 and $367 \mathrm{~nm}$, with the corresponding coefficients of correlation are the following:

$\begin{array}{ll} & \text { myricetin } \\ 254 \mathrm{~nm}: & \\ & \text { area }=6,4198 \cdot 10^{6} \gamma \\ 367 \mathrm{~nm}: & \mathrm{R}^{2}=0,9995 \\ & \text { area }=7,2800 \cdot 10^{6} \gamma \\ & \mathrm{R}^{2}=0,9989 \\ & \text { quercetin } \\ 254 \mathrm{~nm}: & \text { area }=8,8234 \cdot 10^{6} \gamma \\ & \mathrm{R}^{2}=0,9995 \\ & \text { area }=8,7838 \cdot 10^{6} \gamma \\ & \mathrm{R}^{2}=0,9992 \\ & \text { kaempferol } \\ & \text { area }=6,7326 \cdot 10^{6} \gamma \\ & \mathrm{R}^{2}=0,9989 \\ & \text { area }=8,0530 \cdot 10^{6} \gamma \\ & \mathrm{R}^{2}=0,9999\end{array}$

The sensitivity of the method was determined for quercetin by construction of a calibration curve in the concentration region approximated as a detection and quan- 
tification limit $(550 \mathrm{mg} / \mathrm{ml})$. The regression equation or the low concentration curve for quercetin is: area $=8.7913 .106 \mathrm{~g}$ (quercetin), $S D=11278, \mathrm{R} 2=0.9980$.

The limit of detection was calculated as three times the ratio between the $S D$ and the slope of the low concentration curve $(\mathrm{LD}=3 \cdot \mathrm{SD} /$ slope $)$ and the limit of quantification as ten times this ratio ( $\mathrm{LQ}=10 \cdot \mathrm{SD} /$ slope $)(21)$. For quercetin the LD and LQ were found to be $0.004 \mathrm{mg} / \mathrm{ml}$ and 0.013 $\mathrm{mg} / \mathrm{ml}$, respectively. Having in mind the comparable characteristics of these three compounds, the values for LD and LQ for myricetin and kaempferol were estimated according to the ratio of the slopes of the calibration curves for quercetin and the other two flavonols. In this way the LD for myricetin and kaempferol was estimated as 0.005 and $0.004 \mathrm{mg} / \mathrm{ml}$, and the LQ as 0.016 and $0.014 \mathrm{mg} / \mathrm{ml}$, respectively.

The content of myricetin, quercetin and kaempferol in investigated herbal drugs were determined in the extracts obtained after acid hydrolysis of the plant material and extraction of aglycones with ethylacetate. The results are presented in Table 2 . The content of total quercetin ranged from $0.026 \%$ in Bursae pastoris herba to $0.506 \%$ in Pruni spinosae flos, while the content of total kaempferol ranged from $0.026 \%$ in Uvae ursi folium to $1.246 \%$ in Pruni spinosae flos. $0.102 \%$ myricetin was determined in Betulae folium.

According to the obtained chromatograms, only the investigated three flavonols together with the one marked as $\mathrm{X}$ were identified as flavonoid compounds. They all have similar UV-spectra (especially myricetin, quercetin and X) which justifies the introduction of a method for estimating the quantity of total flavonols in terms of quercetin as the most readily available of all flavonoids. This method involves summation of the areas of the peaks attributed to flavonols (according to UV-spectra) obtained at $367 \mathrm{~nm}$ and calculating the content of total flavonols expressed in terms of quercetin. The results from application of this approach are presented in the last column of Table 2, where according to this criterion the flavonol content ranges from 0.040 to $1.680 \%$ for Pruni spinosae flos which is the richest sample in content of flavonols.

It is well known that Betulae folium and Sambuci flos are appreciated in phytotherapy because of their flavonoid content. Among other measurements, quality control of these herbal drugs includes spectrophotometric determination of total flavonoids with $\mathrm{AlCl}_{3}$ (5). Thus the content of total flavonoids in Betulae folium should not be less than $1.5 \%$ expressed as hyperozid, as well as $0.8 \%$ for Sambuci flos, calculated as isoquercitrin (5). In quality control of Tiliae flos determination of the swelling index is accepted as a quantitative standard although it is well-known that flavonoids are probably the most important active components in this drug. Other specimens, such as Primulae flos, Pruni spinosae flos and Robiniae pseudoacaciae flos, contain predominantly quercetin and kaempferol as flavonol components (1-5). No method for quantitative determination of these components was suggested until now. On the other hand, in quality control of Uvae ursi folim determination of arbutin was accepted as quantitative standard. Among other investigations, bitterness index for Centaurii herba and hemolytic index for Herniariae herba were accepted as tests for evaluation of their quality, as well.

The present work offers a new and rapid HPLC method for assay of flavonols and determination of myricetin, quercetin, kaempferol and total flavonoids in herbal drugs, which can be used in routine analysis of these plant materials. The method is particularly recommended for the herbal drugs for which no method for quantitative standardization has been proposed yet.

Table 2. Results from determination of myricetin, quercetin, kaempferol and total flavonoids in air dried plant material (in \%)

\begin{tabular}{llcccc}
\hline \hline & Plant material & $\begin{array}{c}\text { Myricetin } \\
\omega / \%\end{array}$ & $\begin{array}{c}\text { Quercetin } \\
\omega / \%\end{array}$ & $\begin{array}{c}\text { Kaempferol } \\
\omega / \%\end{array}$ & $\begin{array}{c}\text { Total flavonoids } \\
(\text { in quercetin) }\end{array}$ \\
$\omega / \%$
\end{tabular}

* the flavonol $\mathrm{X}$ is also considered;

mean average content $\pm \mathrm{SD}(\mathrm{n}=3)$. 


\section{Conclusion}

HPLC analysis of flavonols in 10 herbal drugs of Macedonian origin, showed that quercetin is the most abundant flavonol in Uvae ursi folium and Pruni spinosae flos. Kaempferol was most abundant in Pruni spinosae flos and Robiniae pseudoacaciae flos, whereas myricetin was identified only in Betulae folium. The content of quercetin ranged from $0.026-0.506 \%$, while for kaempferol it was from traces to $1.246 \%$. The proposed HPLC method for identification and determination of myricetin, quercetin, kaempferol and total flavonoids is rapid and suitable for use in routine analysis of flavonols in herbal drugs.

\section{References}

1. I. Asenov and S. Nikolov. Farmakognozia, Medicina i fiskultura, Sofia, 1988.

2. J. Bruneton, Pharmacognosy, Phytochemistry, Medicinal Plants, Lavoisier Publishing, Paris, 1995.

3. N. Kovacevic, Osnovi farmakognozije, MJM, Beograd, 2000.

4. N. Newall, L.A. Anderson and J.D. Phillipson, Herbal Medicines, A Guide for Helthcare Proffesionals, The Pharmaceutical press, London, 1996.

5. M. Wichtl, Herbal Drugs and Phytopharmaceuticals, Medpharm Scientific Publishers, Stuttgart, 1994.

6. P.C.H. Hollman, M. G. L. Hertog and M. B. Katan, Food Chem., 57 (1) 43-6 (1996).
7. J. B.Harborne and T. J. Mabry, In The Flavonoids: Advances in Research, Ed. J. B. Harborne, T. J. Mabry, Chapman and Hall, London-New York, 1982.

8. T. J. Mabry, k. R. Markham and M. B. Thomas, The Systematic Identification of Flavonoids, Springer-Verlag, New YorkHeidelberg-Berlin, 1970.

9. Pharmacopoeia Helvetica editio septima, Eidgenossiche drucksachen - und Materializentrale, 3000 Bern, 1987.

10. S. Kawaii, Y. Tomono, E. Katase, K. Ogawa and M. Yano, J. Agric. Food Chem. 47, 3565-71 (1999).

11. S. Karakaya and S. N. El, Food Chem., 66, 289-92 (1999)

12. S.H. Hakkinen, S. O. Karenlampi, I. M. Heinonen, H. M. Mykkanen and A. R. Torronen, J. Agric.Food Chem., 47, 2398-2403 (1999).

13 A. Crozier, M. E. J. Lean, M. S. McDonald and C. Black, J. Agric. Food Chem., 45, 590-595 (1997).

14. H. Vuorinen, K. Maatta and R. Torronen, J. Agric. Food Chem. 48, 2802-2806 (2000).

15. M. Ollanketo and M. L. Riekkola, J. Liq. Chromatogr. Relat. Technol., 23, 1339-1351 (2000).

16. S. Kulevanova, M. Stefova and T. Stafilov, Pharmazie 55, 391-392 (2000).

17. S. Kulevanova, M. Stefova and T. Stafilov, Acta Pharm., 50, 29-37 (2000).

18. S. Kulevanova, T. Stafilov, F. Anastasova, M. Ristic and D. Brkic, Pharmazie 52, 886-888 (1997).

19. V. Dervenxi, Sovremeno lekuvawe so lekoviti bilki, Tabernakul, Skopje, 1994.

20. V. Bankova, S.S. Popov and N. L. Marekov, J. Chromatography, 242, 135-143 (1982)

21. Reviewer Guidance, Validation of Chromatographic Methods, Center for Drug Evaluation and Research (CDER) FDA, 1994. 


\title{
Резиме
}

\section{HPLC идентификација и определување мирицетин, кверцетин, кемферол и вкупни флавоноиди во растителни дроги}

\author{
Светлана Кулеванова1*, Марина Стефова², Татјана Кадифкова Пановска ${ }^{3}$ рајче Стафилов²

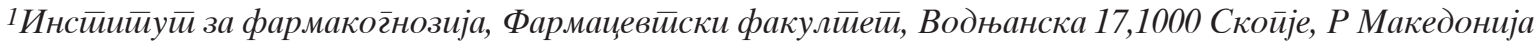

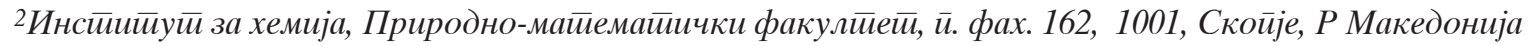

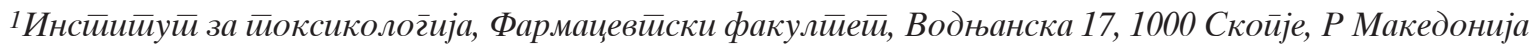

Клучни зборови: флавоноли, кверцетин, кемпферол, HPLC

Во трудот е претставен нов и брз HPLC метод со спектрофотометриска детекција за идентификација и определување кверцетин, кемферол, мирицетин и вкупни флавоноиди во десет растителни дроги од македонско потекло. Подготовката на растителниот материјал (Uvae ursi folim, Pruni spinosae flos, Sambuci flos, Betulae folim, Primulae flos, Herniariae herba, Centaurii herba, Tiliae flos, Bursae pastoris herba) вклучува хидролиза на хетерозидните облици на флавоноидите и екстракција на вкупните флавонски агликони со етил ацетат. Во НPLC анализата е користена реверзно фазна колона $\mathrm{C} 18$, градиентно елуирање со смеша од 5\% оцетна киселина и ацетонирил и температура на колона 30 ㄷ. Квалитативната анализа на флавоноидите покажа присуство на кверцетин во девет испитувани примероци, додека кемферолот беше најден во седум. Квантитативната анализа покажа дека кверцетинот е застапен во количество од 0,03-0,51 \%, а кемферолот од траги до 1,25 \%. Uvae ursi folium (0,49 \%) и Pruni spinosae flos (0,51 \%) се суровини најбогати со кверцетин. Суровини богати со кемферол се Pruni spinosae flos (1,25 \%) и Robiniae pseudoacacie flos $(0,89$ \%). Предложениот HPLC метод е погоден за рутинско определување кверцетин, кемпферол, мирицетин и вкупни флавоноиди во наведените растителни дроги. 